\title{
外国文献抄訳
}

Anesthesia in Rhinology : M.J. Marmer,

Laryngoscope 73, 1636, 1963.

鼻秥手術の各種麻酔法について綜説的に述へ，その中 で全麻法および催眠術の応用について強調した，勫科手 䘗では気管内插管による吸入麻醉法が気道確保などの点 から特に効果的であり，この各種薬剂の中で halothane (Fluothane) が多くの利点を有しているので，これた ついて詳述した，局麻で岵 lidocaine (Xylocaine) mepivacaine (Carbocaine)などが多く用いられてい る. 最近麻䣲医は催眠術を再検討し，麻醉学の分野に応 拥している、隻眠術は麻䣲に代るべきものではないが， その暗示によつて，患者の精神的不安，興寉や，肉体的 苦痛を減少玉たは消失させ得るから，麻醉の補助として これを用いることは非常に効果的である，局麻で行う鼻 の手術の多くは local anesthetics に頼ることがあるか ら，術前，術中に多くの暗示を与支ることは有益であ る. 小少では麻酔の導入や基眐麻酔の目的に催眠術は有 效な方法であり，また局麻剂などの薬物に対するアレル ギー患者に対しても，これは大いに価值がある。

Sinusitis in Children with Bronchiectasis,

(The Influence of Allergy on its Development)

J. SZPPUNAR, \& B. OKRASINSKA,

Arch. of Otolaryng. 76, 1636, 1962.

小児では副番腔炎に気管支搪張症が合倣することはよ く知られているが，その成因として呩性分泌物が下行性 に副鼾腔から気管支へ，また逆に上行性に進展すること も考克られ，更にこ机にレルギーが大きな役割を演ず ると考之られている。著者は化䑋性気管支拨張症の小児 200 名中で 50 例 $(25 \%)$ 亿急性慢性副鼻腔炎を認めた。 これらの症例について上頻洞㧍よび気管支の分泌物から 細菌検查を行ない，両者の細菌稀にかなりの相似性 (72 \%)を認めた，更にこの細菌感没を起こし易くする素因 として鼻，副家腔粘獏のアレルギ一性変化の存在を重要 視した。

そこで本症の治療として，感受性をもつた抗生珮の便 用とともに，長期間根気上く抗アレルギー療法 (Hydrocortisone など）を併用することが最る効果的である。 とくに radical thoracic snrgery の前準備として, ま た全身状態の悪化した場合にその価値を認める。この副 鼻腔炎の有効適切な治療で，上下気道の悪循環を断ち切 ることによつて，気管支の状態の著明な好転をもたらし
得た。

Blue Eardrum due to Cholesterin Granuloma :

G. Bod6, Acta otolaryng 56, 11, 1963.

特発性青色鼓膜の 1 例を報告する。症例は 21 才の男 子で 3 才の時右側乳突削開術をうけている. 所見として は豉膜の青色变化と, 内陌及びはん痕菜縮をみとめる。 㯖力はかなり低下し，骨導では 4,000c/s 以上は聴取不 能である。再手術で耳後創に濃厚な軟亮状の緑褐色の熄 と鼓室に粘稠な緑褐色の分汹物をみとめ、これらを除 去，吸引した後に健全なる耳小骨連鎖及び鼓室粘膜をみ とめた，そして鼓膜の青色は消退し，聴力は改善した． この塊及び分汹物は無菌的で，多数のコレステリン結晶 を鏡検し得た。術後8 日目に両び鼓膜は青色となり，聴 力は低下した. 2 力月間に鼓膜切開が 10 回行われ，通 気も施行したが分泌物の産生を阻止する事が出来ず，患 者も来院しなくなつた。

文献によるとこの現象の背景として乳案部のコレステ

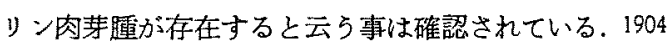
年来種々の報告があるが，ぞうしてコレステリン肉䓇遇 が乳突部に発生するか, 又チョコレートブラウンの液体 の原因は何か未だ明白ではない，併し原因として慢性炎 症が下地にあり，長期に亘り無菌的《経過し，肉苏腫が 形成されると，鼓室又は乳突部に陰圧を生ぜしめ，そし て血清の浸出が起りらる事柱可能であると思われる。こ の血清中のコレステリン結晶が粘膜の中に肉茅を形成す るのであららか。治療としては鼻咽腔, 耳管の処固と肉 莱腫の除去炕あるとのべている。

\section{Zur operativen Versorgung der}

Labyrinthfisteln: K. Krumpholz,

Mshr. Ohr. heilk. 96, 403, 1962.

自然の迷路㿉は真珠尰を伴う慢性中耳资に多発するが 瘦孔症状又は正迫症状のみで診断をするのは不確実であ る，瘦孔症状陰性の場合でる迷路瘦がある場合がある事 を考虑すべきである，一般に迷路癄の手術の場合，周固 を廊清してから，骨細片，結合織片，移植皮虞弁等で漊 を閉鎖するが，この際内耳に影響なきよら極く控兄目に 処管する事が重要である．特に鼓室形成で第而型の場合 には，震を骨細片でしつかり上閉鎖する班が聴力上の見 地から大切である。なぜならもし移植皮荫弁から慣孔を 通つて音波が内耳に伝われば，移植皮筬弁から鐙骨を通 つて卵円空から内耳に伝わる高波之両者間には位相の相 違があるので，却つて聴力低下をもたらすからである. 